\title{
NAUKA JĘZYKÓW OBCYCH UCZNIÓW Z DYSFUNKCJĄ SŁUCHU
}

\author{
BARBARA SKOWRONEK
}

\begin{abstract}
Hearing impaired people have serious communication problems: both with (full) understanding of reality and with learning the first language. In order to counteract communication exclusion, they compensate for the deficiencies with an increased use of other senses. They learn the first language consciously with the help of a speech therapist, compensating for hearing dysfunctions, e.g. wide-angle vision. Karpińska-Szaj calls such learning inclusive; they can be successfully used in teaching foreign languages.
\end{abstract}

Key words: hearing impairment; teaching foreign languages to hearing impaired students

0. Człowiek przychodzi na świat z dwojgiem oczu, dwojgiem uszu i (jednymi) ustami. To umożliwia mu postrzeganie świata (zwłaszcza) poprzez widzenie, słyszenie i mówienie. Dzięki temu każdemu człowiekowi wrodzona jest zdolność do komunikowania się za pomocą zmysłów i za pomocą języka (który odróżnia człowieka od zwierząt). Oznacza to też posiadanie zdolności do nabywania (uczenia się) języka, by za jego pomocą zdobywać wiedzę i umiejętności. Zarówno zmysły jak i język pomagają człowiekowi orientować się $\mathrm{w}$ otoczeniu i komunikować się $\mathrm{z}$ otoczeniem innych ludzi. Do orientacji w otoczeniu, także do uczenia się najbardziej potrzebne są oczy, uszy i usta (i sprawnie funkcjonujący rozum).

Dysfunkcje sensoryczne wpływają negatywnie na możliwości komunikacyjne człowieka i jako nadawcy i jako odbiorcy, bo odbierają człowiekowi (a przynajmniej poważnie utrudniają) możliwość nauczenia się języka: brak słuchu oznacza brak kontroli (człowiek jest niemy, bo głuchy). Zdecydowana większość ludzi posługuje się językiem dźwiękowym, i tego oczekuje się od innych, także od ludzi z dysfunkcją słuchu. Kto nie mówi, jest traktowany (zdecydowanie niesłusznie) jako niezdolny do komunikacji, niekomunikatywny, nierozumiejący i nierozumiany. 
Celem artykułu jest odpowiedź na pytania: Jak komunikują się ludzie z dysfunkcją słuchu? Jak uczą się języka pierwszego? Czy (i jak) mogą uczyć się języka obcego?

1. Człowiek jako istota społeczna (homo socius) jest wyposażony w zdolność do komunikacji językowej i niejęzykowej (homo communicans): to pozwala mu orientować się w otoczeniu, czyli dostosować się do otoczenia ale i wpływać na otoczenie, zmieniać je. Zdolności komunikacyjne człowieka obejmują możliwość stosowania wiedzy językowej (semantycznej i pragmatycznej o formach, funkcjach i realizacji wypowiedzi) i niejęzykowej (kulturowej w szerokim znaczeniu) do celów komunikacyjnych (Olpińska-Szkiełko 2012: 446). Według Gruczy (2012) człowiek wyposażony jest $\mathrm{W}$ wiedzę genetyczną (Erkenntnispotential) i nabytą (Entwicklungspotential). Wiedza genetyczna jest naturalna, wrodzona, przekazywana z pokolenia na pokolenie, dana wszystkim istotom żyjącym i wystarcza do istnienia, orientacji i dostosowania się do otoczenia w podstawowych funkcjach życiowych zwłaszcza zdobywania pokarmu i rozrodczości; to indywidualne respektowanie otoczenia i akceptacja otoczenia. Wiedza nabyta uzdalnia człowieka do rozwojowej orientacji $\mathrm{w}$ otoczeniu, polegającej nie tylko na dostosowaniu się do otoczenia ale i wpływanie na otoczenie, wprowadzanie zmian; ta wiedza jest rozwijana, zdobywana na kanwie wiedzy wrodzonej, wypracowana staraniem (uczeniem się) konkretnej osoby (jako ucznia) w procesie uczenia się.

Już małe dziecko orientuje się w otoczeniu nonwerbalnie: obserwuje je za pomocą zmysłów, zwłaszcza oczu i uszu, całym ciałem odpowiadając na rytm otoczenia, raczej biernie dostosowuje się, by realizować swoje potrzeby (zaspokojenia głodu czy czystej pieluszki). Z czasem dziecko staje się aktywniejsze, nie tylko dostosowuje się naśladując, ale rekonstruuje, generuje własną wiedzę, uczy się respektować i akceptować otoczenie językowo-kulturowe; wpływa też na rozwój otoczenia, staje się kreatywne drogą odważnych decyzji. Małe dzieci zaczynają uczenie się otoczenia obserwując, słuchając, patrząc - naśladują, czyli uczą się imersyjnie otoczenia w otoczeniu i od otoczenia. Małe dziecko rozpoczyna naukę języka od naśladowania dźwięków: akustycznie i prozodycznie, naśladuje głównie intonację, rytm wypowiedzi. We wczesnym dzieciństwie dominują wpływy genetyczne, dziecko poddaje się wpływowi otoczenia: całym ciałem reaguje na bodźce otoczenia, dostosowując się do rytmu otoczenia zwłaszcza gestyką, mimiką, wykorzystuje też oczy i uszy do postrzegania otoczenia i socjalizacji, wartościowania pozytywnego i/lub negatywnego. Dość szybko zaczyna wpływać na otoczenie. Bardzo ważny jest całokształt dźwięków otaczającego świata, m.in. dobra muzyka inspiruje, porządkuje, nadaje rytm, pociesza, uspakaja emocje, wycisza. Najpełniejszym instrumentem muzycznym jest głos ludzki.

Językowe i niejęzykowe poznawanie świata, a więc i uczenie się, dokonuje się za pomocą zmysłów, które umożliwiają widzenie, słyszenie, wąchanie, czucie, do- 
tyk, smakowanie. Wrażenia zmysłowe przekazywane są do mózgu, gdzie dokonują się właściwe procesy przetwarzania kognitywnego celem zapamiętywania; tak tworzy się doświadczenie życiowe człowieka. Właściwym organem językowym jest mózg: akwizycja języka pierwszego polega na wytwarzaniu stałych relacji między komórkami nerwowymi (synapsami) w mózgu, w którym dokonuje się przetwarzanie informacji. Dlatego dziecko potrzebuje bardzo wielu bodźców akustycznych z otoczenia, które naśladuje. Jeśli nie otrzymuje wystarczająco dużo bodźców, zapomina, bo bodźce akustyczne nie zostały wystarczająco wzmocnione. Dziecko wprawdzie uczy się szybko, ale równie szybko zapomina, dlatego konieczne jest ciągłe powtarzanie. Dziecko uczy się języka próbując dostosować się społecznie do otoczenia: zrozumieć i naśladując mówiące otoczenie - ocenia, rekonstruuje język otoczenia. Powoli i skutecznie powstaje jego wiedza proceduralna (co?) i wiedza dyrektywna (jak stosować?). Ten proces uczenia się wzmacniany i poszerzany jest następnie w nauczaniu szkolnym: uczeń interpretuje teksty akustycznie i prozodycznie, gramatyczno-semantycznie i pragmatycznie. Ten aktywny odbiór, generowanie wiedzy przez indywidualnego ucznia, to kreatywne działanie ucznia jako podmiotu nauczania (według zasady „Uczyć się, a nie być nauczanym”, Wilczyńska 1999)

Małe dziecko niesłyszące (pozbawione zdolności słyszenia) ogranicza się do wrażeń wzrokowych, czyli obserwacji i oceny mowy ciała osób z otoczenia; dysfunkcja słuchu pozbawia dziecko możliwości kontroli: jest nieme, bo nie słyszy i dlatego nie może nauczyć się języka dźwiękowego.

2. Komunikowanie się jest procesem symbolicznym, realizowanym za pomocą znaków materialnych: językowych i niejęzykowych. Znaki te, tworzone w ramach społecznej umowy, stają się konwencjonalnymi symbolami, rytuałami w procesie porozumiewania się; odbierane są zmysłami, mogą wyrażać, zastępować cokolwiek. Komunikacja ludzka to różnorodność znaków i sposobów nadawania/odbioru; to interpretacyjny przekaz informacji, wiadomości, wiedzy, przekonań, doświadczeń itd. między nadawcą a odbiorcą, to także wyrażanie postaw, stanów psychicznych oraz zawieranie lub przerywanie relacji międzyludzkich (Tomaszkiewicz 2006). Komunikacja nie jest symetrycznym transportem informacji od nadawcy do odbiorcy: nie zawsze informacja nadawcy jest odebrana idealnie zgodnie z zamiarem nadawcy. Komunikacja służy porozumiewaniu się, kontaktowaniu się z innymi ludźmi, nawiązywaniu i rozwijaniu relacji z otoczeniem, poznawaniu rzeczywistości, współistnieniu w otoczeniu; komunikacja to dostosowanie się człowieka do otoczenia i wpływanie na nie.

Można zauważyć relacje zwrotne między komunikacją, postrzeganiem rzeczywistości i uczeniem się. Zdolność do komunikowania się wyzwala w człowieku potrzebę uczenia się, implikuje możliwość zdobywania wiedzy i umiejętności. Wiedza pozwala na większą samodzielność myślową i społeczną, ułatwia komunikację. Efektem komunikowania się międzyludzkiego jest poznawanie rzeczywistości. Po- 
strzeganie i poznawanie świata/rzeczywistości odbywa się językowo i niejęzykowo; dokonuje się przez uczenie się, czyli zdobywanie wiedzy i umiejętności w otoczeniu społecznym; odbywa się to dwojako: naturalnie, za pomocą wiedzy wrodzonej i/lub kulturowo, w sposób nabyty, za pomocą wiedzy wyuczonej. Wiedzę przekazuje się niemal wyłącznie za pomocą języka (umiejętności za pomocą zmysłów i języka).

3. Efektywna komunikacja jest wynikiem poznawanie rzeczywistości za pomocą środków językowych i niejęzykowych (parawerbalnych, niewerbalnych i ekstrawerbalnych).

Środki językowe to wszystkie środki wyrazu języka akustycznie realizowanego i zapisanego łącznie $\mathrm{z}$ metaforami, wieloznacznościami, tym co niewymówione a zamierzone w słuchaniu, mówieniu, czytaniu, pisaniu. Według Gruczy (1993: 31) język jest wiedzą praktyczną konkretnego człowieka, która umożliwia mu realizowanie konkretnych celów komunikacyjnych za pomocą wyrażeń/ wypowiedzi nadając im funkcje znaku; człowiek uczy się rozpoznawać wyrażenia tworzone przez innych, czyli identyfikuje je i różnicuje posługując się językiem; czyta lub słucha i rozumie zawarte w nich znaczenia, treści i sens. Język jako właściwość komunikacyjna człowieka jako nadawcy/ odbiorcy istnieje razem z właściwościami kulturowymi, które służą komunikacji (Grucza 2012). Człowiek jako uczestnik komunikacji jest istotą generującą język, wiedzę i kulturę (Grucza 1997: 15).

Środki parawerbalne to różnorodne środki służące wyeksponowaniu lub zduszeniu wypowiedzi ustnej, to artykulacja wraz z prozodią, czyli dźwięki, symbole, przerwy, siła głosu, trwanie, tempo mówienia, akcent wyrazowy, intonacja tekstu, szumy towarzyszące jak śmiech, płacz, pomruki, krzyki itd.; wymowa i słyszenie determinują czytanie i pisanie. To także pisane możliwości dodatkowe jak tabele, szkice, obrazy (główny i tło), piktogramy; światło, cień, dźwięk i cisza, kolory, formy itd. Środki niewerbalne są realizowane za pomocą mowy ciała (i zmysłów: gesty, miny, dotyk), muzyka, ruch, taniec (pantomima), oddalenie (proksemika) zwłaszcza by wyrazić zachowania psychiczne, emocje. Środki ekstrawerbalne to całokształt warunków zewnętrznych determinujących proces komunikacji, kontekst społeczny, czyli kto z kim, dlaczego, gdzie komunikuje; to czas, miejsce, klimat, oświetlenie itp., wyrażające lub ukrywające zamiary komunikacyjne uczestników komunikacji.

Powyższe środki wpływają na komunikację jako interakcję, w której tworzone są znaczenia, treści i sens wypowiedzi; wpływają na jej efektywny przebieg. W trakcie komunikacji tworzone są relacje społeczne w grupie społecznej (przerywane/ podtrzymywane/ zmieniane/ itd.). Puppel i Puppel 2008 wymieniają trzy rodzaje sposobów wzajemnego wpływania ludzi komunikujących się: monomodalne (audiowokalne słuchanie), bimodalne (widzenie i dotykanie, a więc pisanie), multimodalne wpływanie (słuchanie - mówienie - widzenie - pisanie). Najczęściej komunikacja przebiega multimodalnie, realizuje się w podstawowych sprawnościach językowych słuchanie i mówienie, pisanie i czytanie. 
Niejęzykowe środki komunikacyjne to wrażenia sensoryczne, czyli multimedialne, subiektywne reprezentacje wiedzy i umiejętności człowieka. Mogą ułatwiać odbiór, poszerzać, ale także utrudniać, gdy nie ma zbieżności między zamiarem nadawcy a oczekiwaniem odbiorcy lub gdy przekazuje się za wiele informacji. Mowa ciała, często synonim komunikacji niewerbalnej, to całokształt środków zmysłowych używanych zamiast, bez języka lub uzupełniając język; daje informacje (świadome lub nieświadome) o uczestnikach komunikacji, zarówno o nadawcy jak i odbiorcy, o ich wzajemnych relacjach, oraz o przedmiocie interakcji; steruje przebiegiem rozmowy w aspekcie wzrokowym, słuchowym, gestyki, mimiki, haptyki, olfaktoryki, proksemiki, kinetyki. Najściślej z językiem związana jest mimika i gestyka. Gesty i miny towarzyszą wypowiedzi, regulują lub zastępują język, nadają rytm wypowiedzi, wyrażają uczucia, emocje, stany psychiczne, są specyficznie kulturowe (dlatego bardzo ważne w nauczaniu języków obcych); gestykulacja pomaga mówcy ('rozmawiać rękami'), często też słuchającemu (bazgranie w czasie słuchania). Mimika obejmuje różnorodne środki wyrazu twarzy - jako przejaw indywidualnego stanu zachowania, psychiki, nastawienia nadawcy i/lub odbiorcy. Mimika modeluje, zastępuje (lub neguje) to, co wypowiadane językiem; obejmuje także patrzenie, np. w oczy (niepatrzenie w oczy może być przejawem niepewności, obawy, niechęci; w niektórych kulturach jest obwarowane reżimem społecznym). Brak mimiki, podobnie jak brak gestykulacji powoduje u odbiorcy monotonię, nudę czy wręcz podejrzliwość (a może nadawca chce coś zataić?).

O ważności mimiki i gestyki w komunikacji przekonujemy się nosząc maseczki w czasie pandemii covid: twarz w połowie zasłonięta powoduje znaczne zubożenie komunikacyjne, wręcz utrudnia zrozumienie, czasami nawet rozpoznanie człowieka. Przekonujemy się też, jak bardzo często (nie tylko w warunkach zakłóceń jak hałas, niepotrzebne szumy) odczytujemy nadawcę $\mathrm{z}$ ust, a nie audialnie.

Haptyka to odbiór wrażeń zmysłowych przez skórę (dotyk), począwszy od podawania dłoni. Proksemika opisuje lokalizację człowieka w przestrzeni, bliskość lub oddalenie, pozycję człowieka wobec innych ludzi, a także wobec mebli, domów, drzew w lesie itd. Kinetyka określa ruch człowieka, albo całym ciałem albo tylko części ciała, np. dłoni, palców, stóp, mrugnięcie powieką, realizowana nie tylko w tańcu, pantomimie (nieraz zaprzecza się temu, co wypowiedziane). Olfaktoryka to wrażenia estetyczne nosa (węch, aromaty, odór).

Bardzo ważna komunikacyjnie jest intuicja, czyli wgląd, poznawanie bezrefleksyjne; bywa nazywana szóstym zmysłem i jest cenna zwłaszcza w sytuacjach zagrożenia. Ponieważ intuicja pozwala przewidywać, antycypować to, co nastąpi, wyrabia wrażliwość na otoczenie, czuwanie nad tym, co się zdarzy, pozwala dokonywać wyboru znaczenia - dlatego jest bardzo cenna dla osób z dysfunkcją sensoryczną.

4. Najlepiej, gdy wszystkie zmysły funkcjonują prawidłowo, wtedy człowiek ma optymalne warunki komunikacyjne. Nieprawidłowe funkcjonowanie jednego zmy- 
słu lub jego brak jest często kompensowane lepszym funkcjonowaniem innego zmysłu: np. dysfunkcja widzenia bywa uzupełniana wrażliwszym słuchem, dotykiem, orientacją w przestrzeni. Dysfunkcja słuchu rekompensowana jest szerokokątnym widzeniem, wrażliwością na dotyk, węch, wibracje. Deficyty słuchu zastępuje się wzmożoną obserwacją otoczenia, mowy ciała rozmówców i dotykiem, wrażliwością na drgania otoczenia, ruchem; dzięki temu ciekawość świata, która jest mobilizacją do nauki nie jest zachwiana. To kompensacja dysfunkcji zmysłowych, sensorycznych, czyli uzupełniające wykorzystanie innego zmysłu, zastąpienie funkcjonowaniem innego zmysłu.

Nieprawidłowo rozwinięty zmysł słuchu, niesłyszenie lub niedosłyszenie oznacza brak odbioru całokształtu dźwięków otoczenia, zatem i niemożność produkcji dźwięków, artykulacji z powodu braku kontroli; to powoduje niemożność dostosowania się społecznego, czyli brak akceptacji grupy i przynależności do społecznej grupy komunikatywnej (Verkehrsgemeinschaft L. Zabrocki 1966). To niemożność komunikowania się: mówienia i rozumienia oraz bycia rozumianym, czyli brak normalnych kontaktów społecznych, a co za tym idzie poczucie odrzucenia, przygnębienie, odosobnienie, osamotnienie, permanentny smutek, pesymizm, depresja. Kto nie słyszy - staje się wykluczony z grupy, wskutek czego czuje się odosobniony, wyizolowany, niepewny, z poczuciem niższości, niskiej samooceny. Brak języka dźwiękowego, czyli zdolności mówienia powoduje dystans społeczny nawet w najbliższym otoczeniu rodziny, przedszkola, szkoły itd., wręcz wykluczenie, odcięcie od naturalnego środowiska komunikacyjnego, co bardzo szybko przeradza się w poczucie bezradności i niższości społecznej; bez mówienia dziecko z największym trudem się uczy, nawet podstawowych czynności. Kto nie słyszy, nie może odpowiedzieć, argumentować, zapytać czy nawet się bronić, bo nie rozumie, co do niego się mówi.

W społeczeństwie ludzi mówiących akustycznie (którzy są niecierpliwi, bo zwykle nie mają czasu) - oczekuje się mówienia, czyli posługiwania się językiem dźwiękowym. Niemówienie wyklucza akceptację społeczną.

A przecież każdy człowiek wyposażony jest w zdolność do komunikacji: językowej i niejęzykowej, zatem ma prawo i do komunikacji międzyludzkiej i do uczenia się, czyli zdobywania i poszerzania wiedzy i umiejętności, co sprzyja jego usamodzielnieniu się! Dlatego pejoratywne traktowanie osób niesłyszących (jako niezdolnych do komunikacji i uczenia się) jest wielce niewłaściwe i niezwykle krzywdzące, bo głuchota jest dysfunkcją słuchu, którą można zrównoważyć funkcjonowaniem innych zmysłów. Dziecku niesłyszącemu należy jedynie akustyczne bodźce zewnętrzne prezentować inaczej, za pomocą innych zmysłów. Dysfunkcja sensoryczna choć jest uciążliwa - nie jest czymś beznadziejnym, lecz wyzwaniem i zadaniem na całe życie. Dlatego szczególnie od rodziny małego dziecka niesłyszącego należy oczekiwać pomocy: w zaakceptowaniu zaistniałego stanu rzeczy i próbie kompensacji braków sensorycznych. Zwłaszcza małe dzieci niesłyszące powinny 
mieć zagwarantowane wsparcie rodziny, szkoły, otoczenia, jako komfort poznawania i uczenia się w dążności do samodzielnego funkcjonowania w otoczeniu.

5. Co oznacza nie słyszeć, czym jest głuchota? Z czego musi zrezygnować osoba niesłysząca? Jak kompensować niesłyszenie?

Głuchota to dysfunkcja sensoryczna, uniemożliwiająca prawidłowy odbiór bodźców zewnętrznych akustycznych, co bardzo utrudnia kontakty międzyludzkie, orientację w otoczeniu: komunikowanie się i uczenie się (także języka), postrzeganie i wyrażanie rzeczywistości. Głuchota może być wrodzona (prenatalna), ujawnić się między pierwszym a siódmym rokiem życia (prelingwalna) lub po 7 roku życia (postlingwalna) (Domagałą-Zyśk, Karpińska-Szaj 2011: 12n.). Do tego dodać należy osoby dorosłe $\mathrm{z}$ dysfunkcją słuchu, które utraciły słuch: poniżej 65 roku życia co 10 człowiek nie słyszy lub źle słyszy; po 65 - co 5. (Kic-Drgas 2013). Dzieci głuche nie mają doświadczenia słyszenia (ewentualnie tylko częściowe); dorośli mają doświadczenie słyszenia.

Dysfunkcja słuchu czy widzenia poważnie utrudnia dostęp do zdobywania wiedzy i umiejętności, do uczenia się, począwszy od nauki języka pierwszego. W Polsce ludźmi z dysfunkcją słuchu zajmuje się surdopedagogika, (łac. surdus oznacza niestyszący), pedagogika niesłyszących, w ramach pedagogiki specjalnej. Główne elementy surdopedagogiki, to diagnostyka, profilaktyka i terapia (zwłaszcza) dzieci niesłyszących i młodzieży celem wychowania, kształcenia i usamodzielniania od początku edukacji aż do pracy zawodowej, czyli pomoc w uczeniu się, w zdobywaniu wiedzy i umiejętności, jako przeciwdziałanie wykluczeniu społecznemu. To także pomoc rodzicom i rodzinom dzieci niesłyszących (którzy najczęściej są osobami słyszącymi). Wsparcie rodziny dzieci niesłyszących jest absolutnie konieczne: jeśli najbliższe otoczenie (rodzina, przedszkole, szkoła) nie przeciwdziała wykluczeniu społecznemu, wtedy w osobie niesłyszącej narasta i utrwala się tym większe poczucie odrzucenia, wykluczenia społecznego. Do zadań surdopedagogiki należy też praca z dorosłymi niesłyszącymi, którzy utracili słuch, jako przywrócenie samodzielności w nowych warunkach utraty słuchu.

Osoby niesłyszące nie są grupą homogeniczną: niektórzy posługują się językiem migowym (manualiści), niektórzy posługują się językiem dźwiękowym (oraliści); niektórzy posługują się zarówno językiem migowym jak i dźwiękowym.

Zdecydowana większość ludzi słyszy (także rodzice dzieci niesłyszących często słyszą) i nie zna języka migowego. Manualiści często pozostają w zamkniętym kręgu ludzi niesłyszących migających. Oraliści nauczyli się komunikować językiem dźwiękowym, którego nie słyszą. Dla wszystkich osób niesłyszących bardzo ważna jest obserwacja mowy ciała rozmówców, gestyki, mimiki itd., szczególnie odczytywanie z ust (niełatwe, bo niektórzy mówią mało poruszając ustami, lub mają usta zasłonięte zarostem; podobnie jak trudne bywa odczytanie tekstu pisanego). 
6. Jak przygotować dziecko niesłyszące do życia w grupie społecznej ludzi słyszących, by czuło się pełnoprawnym członkiem społeczności (wspólnoty komunikacyjnej)? Z pewnością w terapii słuchu powinno się dążyć do wyrobienia samodzielności osoby niesłyszącej w otoczeniu, zarówno rodziny jak i szkoły, pracy, w autobusie, u lekarza itd. Przede wszystkim rodzina (we współpracy z logopedą i rehabilitantem) powinna pomóc dziecku niesłyszącemu jak najszybciej uświadomić i zaakceptować swoją niekomfortową sytuację, dążąc świadomie do nabycia innych środków komunikacji niż język dźwiękowy. Dziecko powinno jak najszybciej otrzymać zastępcze środki komunikacji, m.in. aparat słuchowy (ewentualnie wraz z implantem) i musi nauczyć się z tego korzystać, by móc dostosować się do swego otoczenia społecznego, czyli komunikować się. Nie jest to łatwe, ani dla dziecka, ani dla jego rodzinnego otoczenia, jednak daje dobre efekty integracji komunikacyjnospołeczno-kulturowej, bo przybliża wrażenie słyszenia i zwiększa szansę na w miarę równorzędne komunikowanie się z osobami słyszącymi. (Domagała-Zyśk, Karpińska-Szaj 2011: 12).

Dzisiejsze aparaty słuchowe są niewidoczne i niezwykle pomocne dla dzieci niesłyszących lub słabo słyszących; są malutkie, subtelne, mini-high-tech, można je połączyć ze smartfonem lub/i tv, by dźwięk docierał bezpośrednio do ucha. Funkcjonują one jak urządzenie stereo: mikrofon pobiera dźwięk, przechodzi przez wzmacniacz, głośnik do ucha. Pomagają zarówno dzieciom jak i dorosłym poprawić jakość słyszenia i życia; choć są tylko protezą (podobnie jak implanty), dają namiastkę doświadczenia słyszenia. Aparaty słuchowe muszą być dostosowane do każdego dziecka indywidualnie, bo każdy człowiek ma inną wrażliwość na odbiór dźwięków; powinny być tak dostrojone, by nie dopuścić do odbioru wibracji szumu, zakłóceń, hałasu. Szczególnie hałas bardzo przeszkadza niesłyszącym. Konieczna jest cierpliwość, bo po fazie przyzwyczajenie, przystosowania - następuje lepszy odbiór, słyszenie. W pierwszym etapie osoba niesłysząca musi nauczyć się selektywnego słyszenia, czyli pomijania, nieprzyjmowania szumów, zakłóceń, a odbieranie dźwięków istotnych. Bardzo ważne jest też odpowiednie ustawienie się osoby niesłyszącej do źródła dźwięku.

Dorośli często pamiętają słyszenie, więc aparaty słuchowe przywracają im zdolność słyszenia (dorosły, który stracił czy zatracił słuch niektórych dźwięków, jak nieprzyjemne zgrzyty, wcale ich nie odbiera; mózg przyzwyczaja się, by tego nie słyszeć).

7. Podstawą komunikacji osób słyszących z osobami o różnych dysfunkcjach sensorycznych jest wybór najbardziej aktywnego zmysłu i to on wyznacza drogę porozumiewania się. Osobom słyszącym z otoczenia osób niesłyszących należałoby uświadamiać istotę niesłyszenia; tym bardziej, że głuchota jest niewidoczna, jak np. niewidzenie czy problemy motoryczne. Osoby słyszące powinny wykazać zrozumienie dla osób niesłyszących: chcieć komunikować się, wykazać się cierpliwością, 
dać nieco więcej czasu, mówić nieco wolniej, staranniej artykułować (ustami). (Domagałą-Zyśk, Karpińska-Szaj 2011: 20) Od obojga uczestników komunikacji, zarówno ucznia niesłyszącego jak i osoby słyszącej oczekuje się wzmożonej koncentracji, mówić starannie poruszając ustami, stojąc naprzeciwko siebie, z twarzą nieoślepioną, w odległości około 2 metrów, mówić w normalnym tempie, upewniając się, że dziecko poprawnie słyszy (powtarzać, niezrozumiałe notować). Nie nadużywać mowy ciała, bo nadmiar bodźców, to nadmiar informacji: gestów, mimiki, który utrudnia odbiór, dekoncentruje odbiorcę.

Edukacja dzieci z dysfunkcją sensoryczną powinna odbywać się łącznie z rehabilitacją jak najwcześniej, w pierwszym okresie kształcenia przedszkolnego: albo indywidualnie $\mathrm{z}$ rehabilitantem i nauczycielem albo w ośrodkach dla dzieci z dysfunkcjami. Dopiero potem (np. po roku), gdy przygotowane rehabilitacyjnie, nauczone kompensowania swoich niedogodności - dzieci niesłyszące będą mogły brać udział w nauczaniu ogólnodostępnym, masowym dorównując innym uczniom w przyswajaniu wiedzy i umiejętności. Do szkoły ogólnodostępnej dziecko z dysfunkcjami zmysłowymi powinno (a nawet musi) iść = by nauczyć się autentycznych relacji społecznych z rówieśnikami.

Bardzo ważna jest rola rodziców, przewodnika lub opiekuna osoby niepełnosprawnej. Dlatego należy najpierw edukować rodziców i opiekunów dzieci z niepełnosprawnością sensoryczną, bo oni są pierwszym łącznikiem między dzieckiem a otoczeniem. Pomoc przewodnika /opiekuna powinna polegać na tym, że wprawdzie zastępuje te zmysły, których nie ma lub które funkcjonują niewłaściwie, ale bez nadmiernego decydowania, co osoba ta ma słyszeć, co ma widzieć lub nie = opiekun pełni tylko funkcję informacyjną, czyli nie powinien nadawać znaczenia rzeczywistości; w przeciwnym razie pozbawi osoby niepełnosprawne samodzielności. Trzeba przekazywać wiedzę obiektywną, często też ocenę, choć nie w nadmiarze. Aby dziecko z niepełnosprawnością sensoryczną mogło w miarę dobrze funkcjonować potrzebny jest sztab ludzi: rehabilitanci, terapeuci, opiekunowie. Powinni oni dążyć do usamodzielnienia się dziecka niesłyszącego: im bardziej są świadome rzeczywistości, w której żyją, im więcej mają wiedzy (także o tym, co wolno a co nie) i umiejętności oraz im więcej potrafią wokół siebie zrobić, tym większa jest ich niezależność, samodzielność.

U osoby pełnosprawnej wszystko to, co widzimy, słyszymy, wszystkie pojęcia i wyrazy tworzą aparat pojęciowy, który pozwala odnaleźć się w świecie widocznym, słyszalnym, ale i moralnym. Do licznej wiedzy, która jest przekazywana w naturalny sposób, dziecko niesłyszące nie ma dostępu. Dzieci z niepełnosprawnością nie rozumieją dwuznaczności, nie wiedzą, jakie zachowanie jest właściwe, więc nie zidentyfikują zagrożenia. Dziecko niesłyszące potrzebuje zainteresowania otoczenia, akceptacji, jako podstawa do samodzielności myślenia i działania w otoczeniu - jest to najczęściej niezaspokojona potrzeba. Dziecko zaniedbane emocjonalnie staje się bezbronne, narażone na złe /niewłaściwe wpływy otoczenia. 
8. Trening języka dźwiękowego jest dla dzieci niesłyszących bardzo trudny, choć możliwy: powinien się rozpocząć od starannego uświadomienia dziecku budowy i funkcjonowania aparatu mownego człowieka, dopiero potem rozpoczyna się naukę świadomego oddychania (przeponą). Następnie dotykając krtani logopedy lub matki - dziecko usiłuje wykonać, osiągnąć analogiczne drganie w swojej krtani, co powinno skutkować wydaniem oczekiwanego dźwięku. Jest to ogromna trudność w wydobywaniu dźwięków: nie słysząc - dziecko nie może korygować swych wypowiedzi, bo brak mu systemu kontroli.

Ćwiczenie wydobywania poszczególnych dźwięków odbywa się multimodalnie: wzmacniane jest akompaniamentem trianglu, bębenka, by wywołać rytmiczne, taneczne poruszanie się dziecka (do wyrażania emocji oraz by zapobiec monotonii przyszłego potoku mowy). Wykorzystuje się taniec, który łączy muzykę, ruch, ciało i uczy rytmu, intonacji; pozwala wytańczyć swoje emocje i ucieszyć się ruchem oraz kreatywnym odkrywaniem siebie. Taniec jest narzędziem, dzięki któremu osoba zmagająca się z problemami może lepiej wyrazić siebie, narzędziem do pozbycia się stresu i napięć. Ciało, ruch i taniec może być odzwierciedleniem słowa, jakiego dziecko niesłyszące nie może wydobyć werbalnie; jest językiem niewerbalnym, taniec często może wyrazić więcej niż słowo. Ludzie, którzy nie potrafią się wysłowić, często potrafią to wytańczyć, wyrazić swoje emocje, cierpienie, radość ruchem, rytmem. Kroki, gesty, postawa ciała, terapię tańcem łączy się ze środkami plastycznymi wyrazu jak rysunek, rekwizyt, muzyka, czytanie. Rytm, ruch, taniec - budzi emocje - tak małe dziecko niesłyszące wyraża swoje problemy egzystencjalne i otwiera się na kontakt z innymi: poznaje siebie i w ten sposób nabiera niezależności i samodzielności.

Po nauce dźwięków przychodzi czas na naukę sylab, krótkich wyrazów, wyrażeń; każdy wyraz musi być bardzo dokładnie zrozumiany w wielości znaczeń; w przyszłej rozmowie dziecko będzie musiało każdorazowo antycypować i dokonywać wyboru prawidłowego znaczenia danego elementu leksykalnego. U niektórych osób wytwarza się wrażliwość na drgania, wibracje otoczenia, także muzyki; niem. Horchen, (Neef 2009) (usilne wsłuchiwanie się). To zastępuje odbiór audialny.

Dla osoby głuchej przykładowo język polski (jako język pierwszy czy ojczysty) jest językiem obcym, bo jako pierwszy używany był język migowy. Problem w tym, że składnia języka migowego jest inna niż gramatyka języka polskiego mówionego; w języku migowym operuje się bezokolicznikami: nie: zrobię coś, lecz robić coś. Osoby głuche są bardzo spostrzegawcze i kompensują brak słuchu wzmożoną obserwacją, czyli szerokokątnym, panoramicznym wzrokiem. Dobrze zrehabilitowane potrafią sobie w miarę sprawnie radzić w społeczeństwie; nie rozumieją jednak abstrakcji, uogólnien, dwuznaczności. $Z$ tego powodu często nie potrafią zrozumieć sensu filmu (potrzebują do tego thumacza) (Neef 2009). Jeżeli osoba głucha ma narysować chłopca pod drzewem, to narysuje drzewo z korzeniami, a pod korzeniami leżącego chłopca. Osoby niesłyszące oglądają rzeczywistość jak film (Wacławek 2021: 48n.). 
9. Z pewnością nauka języka dźwiękowego (pierwszego, ojczystego) jest dla osób niesłyszących trudna. Ale możliwa. I pozwala osobie niesłyszącej na autentyczną przynależność społeczną: językowo-kulturową. A skoro możliwa, to dlaczego efektów tych wielkich trudów nie przenieść na uczenie się języka obcego. Przecież uczniowie z dysfunkcją słuchu nie mają trudności ze świadomym uczeniem się języka: języka ojczystego uczą się świadomie, przy pomocy logopedy; zatem nauka języka obcego nie powinna stanowić trudności, co najwyżej swoiste powielenie i uzupełnienie nauki języka ojczystego. Konieczne są tylko właściwe warunki, jak indywidualizacja uczenia się i samoocena. Zawadzka-Bartnik (2010: 25) wskazuje, że powinien być realizowany ogólny cel nauczania języków obcych, czyli zdolność do komunikacji, by rozumieć i być rozumianym, językowo i niejęzykowo. Zindywidualizować należy jedynie techniki nauczania oraz kryteria oceny efektów uczenia się.

Postulować należy nauczanie języka obcego w odniesieniu do osób niesłyszących w ramach nauczania włączającego (Karpińska-Szaj (2011: 3). Nauczanie włączające to program nauczania dostosowany do specyficznych potrzeb uczniów z dysfunkcją słuchu i niesłyszących. Proces nauczania powinien wraz z efektami nauczania być zdeterminowany efektami i terapią uczenia się, zatem porównaniem stanu wyjściowego i końcowego, zgodnie $\mathrm{z}$ autonomią ucznia rozumianą nie jako rywalizacja w klasie (uczniów słyszących) lecz jako udoskonalenie siebie samego. Wiadomo, że uczniowie dysfunkcyjni słuchowo mają problemy z nauką dźwiękowego języka ojczystego. Dlatego do nauczania języka obcego należy uczniów motywować, wskazując na profity znajomości języka obcego, jak choćby szerszy dostęp do źródeł wiedzy (w internecie). Uczniowie niesłyszący nie mają trudności w posługiwaniu się nowymi technologiami informatycznymi - znajomość języka obcego umożliwia im lepszy dostęp do pozaksiążkowych źródeł informacji. Zadaniem nauczyciela języka obcego powinno być przygotowanie specyficznego, zindywidualizowanego sposobu nauczania zawierającego uzasadnienie tej nauki: dostęp do nowych źródeł informacji w ramach nauczania włączającego (Domagała-Zyśk, Karpińska-Szaj 2011: 33).

Szczęśliwie od roku 2010 nauka języka obcego, także dla osób niesłyszących, jest obowiązkowa w polskiej szkole ogólnodostępnej.

Języka ojczystego uczniowie niesłyszący uczą się autonomicznie, świadomie, konstruktywnie i kreatywnie, dążąc do komunikacyjnego posługiwania się językiem (rozumieć i być rozumianym), mając tak przygotowaną niejako matrycę, sposób uczenia się kolejnego języka, który otworzy im dostęp do szerszego i samodzielnego poznawania rzeczywistości. Czyli nauka języka obcego jest swoistym powtórzeniem procesu uczenia się języka pierwszego; a uczenie się języka ojczystego jest bazą do uczenia się następnych przedmiotów, daje dostęp do wiedzy i umiejętności, do komunikowania się w otoczeniu osób słyszących. Daje uczniowi niesłyszącemu dostęp do mówienia dźwiękowego (jako podstawa poprawnej artykulacji i prozodii, która umożliwia komunikację dźwiękową). Tak samo świadomie uczeń niesłyszący uczy 
się każdego elementu leksyki wraz z poprawnością gramatyczną, co umożliwi mu konwersację z osobami słyszącymi.

Uczenie się języka obcego obejmuje także podobne zakresy tematyczne: teksty dotyczące rodziny, zainteresowań, pogody, usług itd., często odwołując się do języka ojczystego, porównując; używa się różnych tekstów, jak monolog, dialog, opis obrazka, swobodna wypowiedź itd.; te środki mają dać uczniowi niesłyszącemu bazę do wyrażania się jako intersubiektywana wymiana myśli z innymi uczestnikami komunikacji. Relacja między językiem pierwszym a obcym powinna być ciągłym dawaniem i braniem, uzupełnieniem komunikatywnym służącym porozumiewaniu się (Karpińska-Szaj 2013: 38).

Uczenie się języka obcego może korzystnie wpływać na rozwój języka pierwszego, wzmacniając świadome uczenie się i pozycję badawczą ucznia niesłyszącego, jego samodzielność intelektualną. Uczeń szybko przekonuje się, że języka obcego uczy się tak jak uczył się świadomie języka pierwszego, więc nie jest trudne; ponieważ jest świadom trudności technicznych w uczeniu się języka pierwszego, dlatego potrafi antycypować trudności w uczeniu się języka obcego, znajomość którego wyraźnie poszerza możliwości zdobywania wiedzy i umiejętności do postrzegania otoczenia (orientacji w otoczeniu i reagowania na otoczenie). Staje się więc aktywny społecznie, kulturowo i komunikacyjnie, jest atrakcyjnym członkiem wspólnoty komunikacyjnej, przynależy do grupy, która go akceptuje. Może wyrażać swoje opinie, a także realizować swoje zainteresowania. Nauka języka obcego daje uczniowi niesłyszącemu wyższą samoocenę, poczucie własnej wartości, bo czuje się akceptowanym członkiem grupy.

Rozpocząć należy naukę języka obcego od poprawnej artykulacji i prozodii począwszy od produkcji poszczególnych dźwięków, innych niż w języku ojczystym; następnie należy ćwiczyć proste teksty obcojęzyczne, jako wstęp do mówienia swobodnego, indywidualnego dźwiękowego (także uwzględniając właściwy akcent wyrazowy i intonację, melodię zdaniową); teksty muszą zawierać osobliwości kulturowe danego języka, inne niż w języku pierwszym. Każda jednostka lekcyjna powinna być dobrze zaplanowana, podporządkowana głównemu celowi nauczania, obejmując tematycznie zagadnienia z otoczenia i zainteresowań ucznia. Nauka gramatyki powinna przebiegać indukcyjnie, od przykładów do uogólnień i reguł, ćwiczona na konkretnych przykładach tekstowych (aktach mowy), a następnie eksplicytnie - jako porównanie z zasadami gramatycznymi języka pierwszego. Powinna polegać na zbalansowaniu praktycznego użycia i teoretycznego wykładu, czyli reguł formacyjnych (fonemicznych i gramatycznych) i reguł funkcyjnych (semantycznych i pragmatycznych) (Grucza 1993: 25n.).

Nauka języka obcego powinna obejmować zarówno mówienie jak i pisanie; pisać powinien uczeń krótkie wypracowania, notować nowe słownictwo, opracowywać diagramy, itd. Sprawność czytania (i pisania) jest bardzo ważna i należy ją podtrzymywać jako samodzielny dostęp ucznia do wiedzy, zarówno czytanej jak 
i pisanej (poprawna pisownia). Teksty czytane dają uczniowi sposobność do samodzielnego konstruowania języka z jego gramatyką i leksyką.

Od uczniów niesłyszących oczekuje się bardzo dużo autonomii: są oni bowiem w sposób szczególny zdani na własne odkrywanie wiedzy i umiejętności, tylko dzięki swojemu wielkiemu zaangażowaniu mogą osiągnąć efekty nadzwyczajne: nauczyć się komunikować z osobami słyszącymi - sami nie słysząc. Powinni mieć prawo zarówno do samooceny swojego uczenia się, jak i współprogramowania (z nauczycielem) zajęć; uczniowie niesłyszący powinni więc być aktywnymi podmiotami w procesie uczenia się, a nie pasywnymi przedmiotami nauczania (Wilczyńska 1999). Wiadomo, że najlepszy nauczyciel nie może nauczyć uczniów niechętnych, pasywnych, znudzonych, niezaangażowanych.

Wiadomo też, że wiedzy nie można nikomu przekazać: każdy musi ją sam, zgodnie z posiadanym stanem wiedzy, doświadczeniem, świadomością zdobyć, wypracować, zbierać, rozwijać, przepracować, rekonstruować, by za pomocą wyrażeń językowych wyrazić, reprezentować (Grucza 1997: 13, 1993: 27, Olpińska 2007: 39., 2009: 42., Lewicka 2007: 132, Olpińska-Szkiełko 2012: 446, Grucza 2012: 305). Doświadczenie szkolne pokazuje, że nauczanie nie jest symetrycznym przekazywaniem i odbieraniem wiedzy; wiedza ucznia wcale nie zawsze jest kompatybilna $\mathrm{z}$ wiedzą nauczyciela przekazywaną $\mathrm{w}$ procesie nauczania lekcyjnego (pomimo usiłowań nauczyciela). Jest tak dlatego, że nasz obraz świata to nie neutralne, obiektywne lustrzane odbicie rzeczywistości, lecz powstająca w społeczności wielkość skonstruowana przez poszczególnego człowieka: u każdego człowieka inna, w zależności od jego wiedzy posiadanej, jego doświadczeń. Uczy się cały człowiek: Nowa wiedza (i doświadczenie) jest aktywizowana (włączana) przez mózg do doświadczeń bieżących (posiadanych) wraz z emocjami, uczuciami, stanami psychicznymi, ponieważ mózg działa rekursywnie, odnosi się do wcześniejszych pokładów wiedzy zawartej w pamięci, w doświadczeniach indywidualnego człowieka (Kic-Drgas 2013).

Zatem do nauczyciela powinno należeć przygotowanie właściwych warunków do tworzenia własnych tekstów ucznia, czyli do rozwoju wiedzy. Nauczyciel może jedynie inicjować, czyli przekazywać wzorcowe (poprawne) teksty jako gotowe przykłady językowe. Zadaniem nauczyciela jest, by za pomocą dyskursu (w postaci tekstów) inicjować, podawać odpowiednie teksty w odpowiedni sposób, do zrozumienia i nadawania $\mathrm{w}$ określonej grupie językowo-kulturowej. Uczeń musi sam osobiście dokonać rekonstrukcji, zestawienia, generować zasady, by nauczyć się stosowania wiedzy i umiejętności.

Zdobywanie i rozwijanie wiedzy językowej i kulturowej jest pracą przygotowującą człowieka zarówno do życia społecznego jak i usamodzielnienia społecznego. Samodzielność to realizowanie się społeczne człowieka w grupie (rodzinnej, szkolnej, zawodowej itd.); w dorosłym życiu to udział we wspólnocie ludzi pracujących, bądź zainteresowanych wspólnym działaniem, wspólnymi celami, interesami, zain- 
teresowaniami, to przygotowanie do życia społecznego. Praca zawodowa wyrabia odpowiedzialność, zdyscyplinowanie, niezależność społeczną; umożliwia człowiekowi pełnienie roli społeczno-zawodowej, umiejscowienie społeczne, przynależność społeczną, czyli akceptację grupy i akceptację przez grupę. Przygotowanie do pracy zależne jest od posiadania wiedzy i umiejętności.

Osoby z dysfunkcją sensoryczną powinny tym bardziej otrzymywać różnorodne (właściwe, godne) oferty pracy, by zajęte zawodowo potrafiły aktywnie wykorzystać możliwości funkcjonowania skompensowanych innych zmysłów - żyć i funkcjonować samodzielnie i akceptowane przez grupę społeczno-komunikacyjną.

Reasumując: Uczniowie niesłyszący są w swojej inności zmuszeni do świadomego uczenia się, czyli planowania zajęć z nauczycielem, pracy własnej, dążąc do jak najlepszych wyników, potrafią swoje wyniki obiektywnie ocenić; do tego potrzebują pozytywnego nastawienia otoczenia i akceptacji innych uczestników komunikacji (uczniów, nauczycieli). Dlatego uczenie się języków obcych nie stanowi wielkiej przeszkody intelektualnej, co najwyżej trudność społeczną (gdy nie akceptuje się ich nieco większych wymagań do uczenia się); cały zbiór strategii uczenia się posiedli świadomie z uczenia się języka ojczystego.

Zatem pytanie nie powinno brzmieć: „Czy zasadne jest nauczanie osób niesłyszących języków obcych?” lecz: „W jaki sposób nauczać?”

10. Niektórzy rodzice dzieci niesłyszących podejmują się trudu przyswojenia dzieciom niesłyszącym języka dźwiękowego (jako oraliści). Zdobycie tej sprawności, choć bardzo trudne, może pomóc zbliżyć się osobie niesłyszącej do osób słyszących.

Przykładem nauczenia i posługiwania się językiem mówionym jest Sarah Neef, 38, osoba niesłysząca, która nauczyła się języka dźwiękowego, począwszy od nauki poprawnego oddychania poprzez naukę produkcji dźwięków (artykulacja + prozodia) do konwersacji. Temu towarzyszy szerokokątne widzenie wraz z odczytywaniem z ust ludzi, z którymi rozmawia. Czytanie z ust to dla rozwoju języka dźwiękowego niełatwa sprawa, raczej długotrwały proces, trwający do końca życia. Od najmłodszych lat uwrażliwiona muzycznie i ruchowo (tanecznie) wypracowała wrażliwość na wibracje dźwięków otaczającego świata (wsłuchiwania się, niem. Horchen). W ten sposób opanowała nie tylko język ojczysty (niemiecki), ale także języki obce (łacinę, angielski, francuski, rosyjski); za młodych lat tańczyła na scenie teatralnej z profesjonalistami. Uczenie się języka obcego przejęła z uczenia się języka ojczystego, niemieckiego; uzupełniła jedynie elementy kulturowe wiedzy językowej i umiejętności. To, co osiągnęła jest wynikiem silnej woli stawienia czoła wyzwaniu dysfunkcji sensorycznej, jaką jest głuchota, oraz długi, nieustanny trening. Dzięki wielkiej pracowitości jest osobą samodzielną i szanowaną: maturę i studia skończyła z wyróżnieniem, jest aktywnie pracującym doktorem psychologii, ma prawo jazdy i prowadzi samochód. 
Uczenie się języka dźwiękowego przebiegało świadomie: najpierw musiała nauczyć się świadomie oddychać przeponowo, następnie przez dotyk krtani matki i logopedy usiłowała wzbudzić u siebie takie same wibracje, by w ten sposób naśladować dźwięki matki czy logopedy. Matka tłumaczyła jej wnikliwie, gdzie, w której części aparatu artykulacyjnego i jak powstają poszczególne dźwięki; uczyła się wiec produkcji dźwięków poglądowo i świadomie, wspomagana rytmem wybijanym na trianglu i bębenku oraz tańcem. Droga była tyleż długa co żmudna, utrudniona brakiem kontroli: nie słysząc, nie mogła stwierdzić, czy dana wibracja spowoduje produkcję oczekiwanego dźwięku. Podobnie trudne było wykształcenie szerokokątnego widzenia oraz odczytywanie dźwięków z ust rozmówców (ludzie często mówią albo niedbale, ledwie poruszając ustami, lub nadmiernie korzystając z mowy ciała). Na początku uczyła się produkować tylko pojedyncze dźwięki, sylaby, następnie proste teksty, akty mowy; to była świadoma praca nad rozwojem wiedzy językowej. Także świadomie (przy pomocy matki) poznawała znaczenie każdej jednostki leksykalnej w różnorodności znaczeń.

Sarah do dziś jest osobą niesłyszącą, ma problemy nie tylko z produkcją dźwięków, ale także (zwłaszcza) z konwersacją: nie może dowolnie uczestniczyć w spontanicznej dyskusji, bo znaczenie każdej jednostki leksykalnej musi rozszyfrowywać pojedynczo, by zrozumieć syntetyczną interpretację możliwych znaczeń, czyli sens wypowiedzi. Zanim to się stanie, rozmowa toczy się dalej; nie nadąża w konstruowaniu znaczeń po to, by móc brać aktywny udział w rozmowie. Poprawności gramatycznej uczyła się najpierw poglądowo, indukcyjnie, na podstawie jednostek leksykalnych; a potem świadomie, jako kodeks reguł gramatycznych, by produkować wypowiedzi nie tylko dźwiękowo i znaczeniowo poprawne, lecz także gramatycznie poprawne (zgodnie z zasadą Helbiga 1992 „Nie ma gramatyki bez leksyki; nie ma leksyki bez gramatyki”). Ponieważ nie ma języka bez gramatyki, język bez gramatyki nie istnieje.

11. Postulować należy umożliwienie uczniom $\mathrm{z}$ dysfunkcją słuchu uczenie się języka obcego z wykorzystaniem wszystkich metod glottodydaktycznych, zarówno metodą bezpośrednią, metodą audiowizualną/audiolingwalną, nauczanie kognitywno-konstruktywne (rozumiejąc-kreatywnie), nie bez nauczania gramatyki i thumaczenia - wszystko to w zależności od możliwości, motywacji i zainteresowań konkretnego ucznia ku samodzielności intelektualno-społecznej i akceptacji grupy społeczno-językowo-kulturowej.

Postulować należy także poszerzenie zakresu glottodydaktyki o nauczanie uczniów z dysfunkcją słuchu/wzroku w ramach nauczania włączającego. Potrzebne są badania nad uczniem dysfunkcyjnym słuchowo/wzrokowo w kierunku nauczania włączającego (inkorporacyjnego), celem integracji uczniów niesłyszących i słyszących, by umożliwić uczniom niesłyszącym samodzielność komunikacyjną. By do postulatów profesor Hanny Komorowskiej (2017) o opracowanie solidnej bazy glot- 
todydaktyki znalazło się miejsce dla postulatów profesor Katarzyny Karpińskiej-Szaj (2013) o włączającym nauczaniu języków obcych uczniów z dysfunkcjami sensorycznymi, zwłaszcza niesłyszeniem i niewidzeniem.

\section{Bibliografia}

Domagała-Zyśk, E. i K. Karpińska-Szaj. 2011. Uczeń z wada stuchu w szkole ogólnodostępnej. Podstawy metodyki nauczania języków obcych. Kraków: Oficyna Wydawnicza Impuls.

Grucza, F. 1993. „Zagadnienia ontologii lingwistycznej.: O językach ludzkich i ich (rzeczywistym) istnieniu". W zbiorze: Bartmiński J. (red.). Opuscula Logopedica in honorem Leonis Kaczmarek. Lublin: UMCS. 25-47.

Grucza, F., 1997. „Języki ludzkie a wyrażenia językowe, wiedza a informacja, mózg a umysł ludzki”. W zbiorze: Grucza F., M. Dakowska (red.). Podejście kognitywne w lingwistyce, translatoryce i glottodydaktyce. Warszawa: WUW. 5-36.

Grucza, F., 2012. „Zum Gegenstand und zu den Aufgaben der Anthropozentrischen Linguistik, Kulturologie und Kommunikologie sowie zur gegenseitigen Vernetzung dieser Erkenntnisbereiche“. Kwartalnik Neofilologiczny LIX.3. 287-344.

Helbig, G. 1992. „Wieviel Grammatik braucht der Mensch?“. DaF 3. 150-155.

Karpińska-Szaj, K. 2013. Nauczanie języków obcych uczniów z niepetnosprawnościa w szkołach ogólnodostępnych. Poznań: Wydawnictwo Naukowe UAM.

Karpińska-Szaj, K. 2015. „Przygotowanie do pracy z uczniami o specjalnych potrzebach edukacyjnych: językowe narzędzia diagnostyczne w praktyce nauczycielskiej”. Neofilolog 45.2. 187-201.

Kic-Drgas, J. 2013. Fremdsprachenlernen im Seniorenalter. Entwicklung und Evaluation von Lehr- und Lernmaterialien für Senioren. Wrocław, Dresden: Neisse Verlag.

Komorowska, H. 2017. Kształcenie językowe w Polsce. 60 lat czasopisma „Języki obce w szkole”. Warszawa: Fundacja Rozwoju Edukacji.

Lewicka, G. 2007. Glottodydaktyczne aspekty akwizycji języka drugiego a konstruktywistyczna teoria uczenia się. Wrocław: ATUT.

Neef, S. 2009. Im Rhythmus der Stille. Wie ich mir die Welt der Hörenden eroberte? Frankfurt/M., New York: Campus Verlag.

Olpińska, M. 2009. Nauczanie dwujęzyczne w świetle badań i koncepcji glottodydaktycznych. Warszawa: Euro-Edukacja.

Olpińska-Szkiełko, M. 2012. „Glottodidaktische Implikationen der anthropozentrischen Sprachentheorie“. W zbiorze: Olpińsak-Szkiełko, M. Grucza, S. Berdychowska, Z. i J. Żmudzki (red.). Der Mensch und seine Sprachen. Frankfurt am Main: Peter Lang, 445-454.

Puppel, S. i J. Puppel. 2008. „Gestosfera jako istotny składnik przestrzeni publicznej“. Oikeios Logos 4. $1-8$.

Tomaszkiewicz, T. 2006. Przektad audiolingwalny. Warszawa: PWN.

Wacławek, M. 2021. „Usłyszeć pomiędzy wierszami”. Przewodnik Katolicki 20. 48-50.

Wilczyńska, W. 1999. Uczyć się czy być nauczanym. Warszawa: PWN.

Zabrocki, L. 1966. „Kodematische Grundlagen der Theorie des Fremdsprachenunterrichts“. Glottoiddactica 1. 3-42.

Zawadzka-Bartnik, E. 2010. Nauczyciel języków obcych i jego niepetnosprawni uczniowie (z zaburzeniami i dysfunkcjami). Kraków: Impuls. 